\title{
CORPORATE GOVERNANCE PRACTICES AND ITS EFFECT ON CORPORATE FINANCIAL PERFORMANCE: A PRAGMATIC EVIDENCE FROM MALAYSIA
}

\author{
Muhammad Tahir Khan ${ }^{*}$, Haseeb Ur Rehman ${ }^{\dagger}$ \& \\ Arsalan Hashmi
}

\begin{abstract}
Current corporate governance failure and financial scandals are the reason for the governance mechanism due to ignoring the adoption of governance mechanisms in corporate practices. The main objective of the paper is to investigate the association between governance mechanism corporate performances based on extant literature and to put a light on the current governance mechanism in the Malaysian firms. This paper emphasizes the compliance of governance mechanism and the role of MCCG in improving the performance of corporate firms. This paper highlights the issues, current corporate scandals, and failure of corporate governance mechanisms in the first and second decades of the $21^{\text {st }}$ century. Various scandals and misconduct are discussed to report the problems allied to corporate governance. This paper addresses the various corporate governance theories, models, and good governance structure. The internal and external governance mechanisms have been discussed in detail to put a light on its influence on corporate performance.
\end{abstract}

Keywords: Corporate governance, Corporate performance, Agency theory, Malaysian firms.

Assistant Professor, Department of Management Sciences, Imperial College of Business Studies, Lahore. Email: dr.tahirkhanm@gmail.com

$\dagger$ Assistant Professor, Institute of Management Sciences, University of Science and Technology Bannu. Email: drhaseeb@ustb.edu.pk

\# Assistant Professor, Department of Management Sciences, PAF - KIET - Karachi. Email: Arsalan.hashmi@pafkiet.edu.pk 


\section{Introduction}

Shleifer and Vishny (1997) argued that principles of governance principles have a vital impact because it affects the maximization of shareholder's wealth, the confidence of the investors and suitable governance mechanism that helps the firm to create a market value of the firm. Previous studies such as Goncharov, Warner \& Zimmermann (2006) argued that the stock market of listed firms in Germany has a higher value of about 3.23 EUR on average due to the compliance with codes and overall the stock markets have 10 points higher compliance as compared to other European stock markets. Adoption and implementation of governance principles always help the firm to improve its performance. Studies confirm the essential role of good governance in the company's practices (Abdifatah, 2012). However, most of the principles in CG cannot be adopted by the Asian listed firms due to the difference in the business and industrial environment, and thus the results of the studies conducted on the western market cannot be applied to the Asian listed firms. Dahawy (2009) argued that merging countries such as Asians and Africans could not adopt the codes from Western countries due to the difference in norms, beliefs, and culture. Sometimes these differences ascend from the economic and political characteristics and their impact on listed firms (Waweru \& Riro, 2011).

Moreover, Waweru et al. (2011) suggested that different countries have different needs of governance mechanisms due to specific business and industrial environments; known as a country-specific factor that affects the performance of listed firms. Hence, the listed firms in particular emerging economies require corporate governance practices that are more suitable to their environment. Okiro (2014) suggested that, mostly in a company, there are no specific rules or principles that are followed by the listed firms. Corporate governance is the best rule and principle that must be adopted by the firm to improve its performance, entice investment, and secure the rights of minority shareholders.

Corporate governance was first introduced in Malaysia in 2001, and after six years, it was revised for the betterment of the firm and introduced new rules and clauses. After GFC (2008), most of the Asian countries revised corporate governance codes, including Malaysia and Pakistan (2012), which introduced some essential principles to be adopted by the listed firms such as non-duality structure and the presence of non-executive directors (NED). Malaysia again revised the corporate governance codes in 2017 and focused on the increase of women directorship on the board for the first time to improve firm performance and meet the international standards of CG. Furthermore, in Malaysia, new guidelines and principles are introduced to be adopted by the listed firm to avoid misconduct and failure (Khan, Jabri \& Saif, 2019). 
To overcome these issues and control the failure of corporate governance, many countries revised their corporate governance practice to be adopted by the listed companies and to control these issues. UK, US, and other European countries revised corporate governance while in Asia Pakistan, India, China, Singapore, and Malaysia introduced the corporate governance codes and revised them in 2007, 2012 and 2017 for the betterment of firm performance and to monitor and secure the shareholder's wealth in the region. Developing economies modified these codes, which are best suitable for the business and industrial environment to improve firm performance. Progressively, it helps the firm and the authorities that the concept of the "one-size-fits-all approach" is not an effective way to attain effective governance practice in a firm (Khan et al., 2019).

The link between $\mathrm{CG}$ and its performance has been examined by different studies in different economies and from the different aspects in the past decades using static models such as OLS (ordinary least square), FE (fixed effect) and RE (random effect) (Fan et al., 2011). However, the results reported by these studies were inconclusive regarding the link between various governance proxies and corporate financial performance (Bhattacharyya, 2015 and Ghazali, 2010). Listed companies had adopted codes of corporate governance in their practice to avoid any scandals, crises, and financial issues such as agency to improve the firm performance and attract capital, which increased the interest of research on corporate governance practice throughout the world. This paper provides details regarding the evolution of governance, Malaysian codes, and the problems, failure, and failure faced by the listed firms.

This paper contributes in multiple ways to the current research. Primarily, it provides current evidence on the relationship in the context of Malaysia. Secondly, this paper also discusses the effect of various internal and external CG on performance. This study also deliberates the revision of the code of CG in Malaysia as the current revised code MCCG (2017).

\section{Problem and Issues}

Failure of corporate governance in an economy is merely caused by inappropriate use or ignoring the implementation of governance principles in the company's practices. Governance failure in the firm is caused by agency issues such as the conflict that arises between the shareholder and the manager. Problems such as ineffective control, shareholders - management conflicts, distribution of rights and duties may arise due to avoiding the best practice in the firm's structures, and thus it affects the performance and the market value of the firm. To gain the trust of the investor and attract colossal capital, the firm needs to adopt the governance mechanisms that show that the firm policies are strong enough, and there is no misuse of financial resources in the firm. In the firm, when the power goes to one hand (when 
there is CEO duality), then it puts wrong impact of the firm in the market. Similarly if there are not specific and specified number of external nonexecutive directors on the board and the firm is not supporting gender equality, then it is considered as the failure of governance practices in the firm.

\section{Corporate Governance Theories}

\section{Agency Theory}

This theory was first established and familiarized by Jensen \& Meckling (1976). Management and Business area were fundamentally influenced by this theory. This theory stated that in the modern business environment, the conflict between principle and agent tends to increase agency cost where ownership and control are separated. It is considered as the leading theory that defines the impact and relationships. Jensen \& Meckling (1976) affirmed that if the owner (shareholders) directly controls the business, then the firm value will shrink due to an increase in agency cost due to the reason that the manager act as the agent to the shareholders. However, most managers work for their interests and accomplish the objectives that are profitable to them, which is the increase in firm value (Haider, Amir \& Khan, 2019). This theory mainly focused on the problems between the owner and the manager.

The conflict between agent and principal increases the agency cost that reduces the performance. Agency theory stated that good governance results in a reduction in agency cost and creates a healthy environment that tends to improve firm performance. The manager has the authority to manage and control the firm decision, but the shareholder can also control the firm by proper monitoring and supervision by external non-executive directors on the board. Supervision and control over the board of directors are costly and consider agency cost, but alternatively, it helps the firm to improve the firm's performance (Rehman, Rehman, Zahid, Jan, and Rehman, 2019).

\section{Stewardship Theory}

This theory emerged as the alternative perspective of agency cost theory, and based on the association between principal and agent, and accurately, it describes the relationship between these two from a structural and behavioral perspective (Pieper, 2010). Both the theories, i.e., agency theory and stewardship theory, predicted the enouncement in the firm's performance but portrayed different assumptions(Madison, 2014). Most of the researchers argued that agency theory provides a necessary and productive frame where the firms solved the associated problems while stewardship theory describes the ideas form explaining the governance structure in the family-based firms (Davis, Allen, and Hayes, 2010). Stewardship theory is being considered as the opposite theory of traditional 
agency theory based on its recommendations regarding various corporate governance mechanisms. Stewardship theory argued that managers are the best stewards and work in the best interest of the shareholders, while internal directors are enough for the various functions of the company, and there is no need for external directors. This theory argued that the internal director is well known to the company's policies and procedures (Madison, 2014). Saif, Khan, Ali, and Wadood (2019) argued that the efficiency of an organization can only be increased if the capabilities of the employees in the organization are improved. Stewardship theory focused on the internal directors due to the vast knowledge and experience regarding the company's processes, functions, dealings, and relationship with the external industrial environment. This theory recommended the specific number of boards of directors to decrease the additional cost and an increase in work efficiency. This theory argued that internal executive directors are loyal and can better manage rather than non-executive directors (Al-Malkawi \& Pillai, 2012).

Stewardship theory focused on the duality structure rather than nonduality and argued that the CEO and chairperson must be the same person to avoid delay in decision making and better firm performance. In contrast, agency theory prefers a non-duality structure on the board to avoid the problem where power goes to one person that might affect the monitoring functions as well (Rodriguez-Fernandez, 2016).

\section{Resource Dependence Theory}

This theory was first presented by Pfeffer in 1972. This theory concentrated on the existence of external directors on the boards in the firm for better monitoring. External directors enhance corporate performance and protect the firm from an external factor that has an impact on corporate performance. NEDs can make a connection with the outside industry and make better understandings with the other firms (Kor \& Misangyi, 2008).

A high quantity of external NED is considered to have a considerable leverage position. Various researches examine the association in the light of resource dependence theory, where most of them reported a positive association between them. Kor and Misangyi (2008) argued that monitoring functions can be better performed by external directors. (Abor, 2008). RDT suggested that external non-executive directors can bring useful resources to the firm that includes various kinds of experiences from other firms.

\section{External Corporate Governance Mechanism}

\section{Market for Corporate Control and Takeover Defenses}

The adoption of the principles of CG is essential where the model of CG is similar to the model of Anglo Saxon. The chance for the firm's takeover increases where the prices of the stock fall due to poor managerial decisions. Therefore, the management and the ownership must take the actions that 
help the firm to improve and sustain the market reputation. The Board of directors needs to adopt the strategies to defend the firms against takeover and acquisition by the large firms in the market. Takeover defenses are different concerning countries, markets, and geographically, but the aim always remains the same. The adoption always helps the firm to improve the firm value in the market and improve firm performance, which alternatively decreases the chances of the takeover.

\section{Capital Structure}

To discipline the managerial staff and other board of directors, companies typically use the configuration of capital structure that helps the firm in a better way to improve firm performance. Rather than an increase in the ownership (through shares issues), the firm focuses typically on debt and pre-determined interest payments. By applying this scenario, the conflict between shareholders and debtholders can increase, and the firm might face agency issues. In contrast, on the other hand, the credit ratings of debtissuing firms can reduce information asymmetry between BOD/managers and debtholders (Myers, 1977).

\section{Independent Audit}

In a firm or company performance, appraisal, and audit function (annually or semi-annually) has a momentous impact. Audit of the financial statements and other standardized statements is also a part of the governance structure for accuracy purposes. The audit of the firm's financial statement takes place for all the stakeholders that include internal/external stakeholders. A firm has its audit structure while they can adopt the services of audit from outside as well. An audit of standardized and non-standardized statement helps the stakeholder of the firm about the actual performance of the listed firm in the stock market. This mechanism gives a broad and accurate idea to the investor about the actual firm standings in the market, and thus it helps the investor and general public to understand the company's performance.

\section{Small Business Relevance}

The importance of $\mathrm{CG}$ is to acknowledge small and medium enterprises as well. Various internal mechanisms and other structures may not be directly adopted by the small business in the world, but still, there are various examples that show the compliance of governance mechanism in the business structures. Monitoring and controlling function and distribution of duties and responsibilities in the business are performed by the owner in different styles, which is also one of the essential parts of the business. Accordingly, if a business needs a loan from the bank, then a bank can demand to comply with several liens and agreement terms and conditions, which is known as an external governance mechanism in the firms. 
Moreover, if the business is a kind of partnership then any partner can demand the audit of the business to know about the actual and accurate value of the business where the business is standing. These were some of the examples of the relevance of governance mechanism with the small business.

\section{Internal Governance Mechanisms in Malaysian Listed Firm}

The link between governance mechanisms-performance has been examined by different scholars in Malaysian listed firms and reported inconsistent results. Some of them reported significant, while others reported insignificant relationships between various proxies for both governance structure and corporate performance. Various well-known scales and financial crisis help the authorities to recognize the significance and implementation of governance mechanisms in the company's structures. Studies reported that one of the significant reasons for AFC 1997 (Asian financial crisis) was the misuse of financial resources and also the lack of corporate governance mechanisms (Zahid et al., 2020).

\section{Board Size}

A good governance structure and its implementation on the company practice is more important to gain trust of the new and upcoming investors. BOD is always responsible for controlling, monitoring, and accountability to the shareholders, authorities, and other stakeholders of the firm. It is measured as "the total number of board of directors on the board"(Bin \& Yi, 2015). Small numbers of BOD are mostly considered as an active board rather than a giant board (Jensen, 1993) due to various reasons suggested by agency theory. On the contrary, some other scholars reported that large size brings useful resources to the firm and connections, as suggested by resource-dependent theory.

MCCG (2007) reported that "every board should examine its size, to determine the impact of the number upon its effectiveness" (Rehman et al., 2020). The average number of BOD must be eight, as suggested by KLSE (Kuala Lumpur Stock Exchange) (Mustapa, 2015). However, these studies found mixed results such as Shukeri et al. (2012) investigated the association and reported the negative relationship with firm valuation (ROE) while AlSwidi et al. (2012) also examined the same and reported a negative association with ROA. Riaz, Khan, \& Shaheen(2017) reported the negative association and argued that it has a significant impact. Therefore the board size must not be enormous that affects negatively and create problems such as miscommunication, delay in decision making, and the precision is less if the size of the board is huge. In contrast, Mustapa (2015) did not find any significant association, while Haji (2014) reported an insignificant association. Some studies also found positive associations as suggested by 
RDT such as Marn \& Romuald (2012), Ibrahim \& Abdul Samad (2011), and Tham and Romoald (2012), and argued that greater board size brings useful resource to the firm in different forms that improve firm performance.

\section{Non-Executive Directors}

External NEDs have a massive influence on corporate performance (Zahid, Rehman, and Asif, 2019). NED is measured as the percentage of total NEDs to the total number of directors on the board. Agency theory and Resource Dependence theory consider its positive impact, while stewardship theory reported its negative impact on firm valuation (Khan, Jabri \& Saif, 2019). From the theoretical consensus, this theory reported its importance in monitoring and controlling function and argued that outside directors are working in favor of firm and the ownership without any biases and perform perfect control and monitoring (Khan, Jabri and Saif, 2019). RDT suggested that outside non-executive directors are the best source of useful resource and links with business industries that helps in networking and increase the firm value while non-executive directors are the experts and can better help in decision making with the multi-skillful experience. MCCG (2012) reported appointing at least one third or 33\% NED on the board (Ahmed Haji, 2014).

The results are inconclusive in the Malaysian market, such as Marn \& Romuald (2012) reported insignificant association and argued that the presence of NED on the board is ineffective due to various factors such as political influence. Some of the studies such as Ghazali(2010), Ponnu(2008), and Rahim, Yaacob, \& Alias(2010) found an insignificant impact in Malaysia. In contrast, various scholars such as Fauzi \& Locke(2012), and Javed et al. (2013) reported a significant positive impact on firm performance that is supported by the theories such as agency and resource dependence theory.

\section{CEO Duality}

CEO duality refers to the board structure where the chairperson (sometimes president) and the CEO is the one person in a company. Although in most of the listed firms, non-duality structure is applied as suggested by agency theory (Nicholson \& Kiel, 2007). It is difficult for the directors and other board members to perform various functions such as monitoring and controlling in case of CEO duality, and all the power goes to the single person and becomes difficult to challenge his decision (Abdifatah, 2014). Agency theory defined it in a way where non-duality structure is helpful in monitoring and controlling function and in improving the performance of the board.

Agency theory reported that non-duality will alternatively reduce the power concentration and thus also reducing the influence of the management and the CEO behavior (Kyereboah-Coleman, 2007). If the chairperson is 
also a CEO, then it affects the monitoring and controlling function because all authority goes to one hand. The non-duality structure diffuses the separate managerial decision and thus helps the firm in solving and minimizing the agency cost as well (Kyereboah \&Coleman, 2007). Agency theory suggested that if the CEO and the chairperson are the same people, then it might be the misuse of resource and power (Hussin and Othman, 2012). From the perspective of stewardship theory, there must be a duality structure to avoid the delay in decisions and decrease interruption of undue bureaucracy. It also suggested that CEOs are the best stewards and always work for the shareholder and a collective serving individual that positively contribute to firm performance (Goh, Rasli, \& Khan, 2014).

Malaysian Codes of Corporate Governance (2007) recommended having a non-duality structure on the board. The reason behind the separation of the role of CEO and chairperson is that duality leadership structure may facilitate them and adopt self-interest behavior after assuming all the power. It weakens the monitoring and controlling function, and the directors and management cannot challenge the CEO's decision directly, which directly or indirectly influences the firm's performance.

\section{Gender Diversity}

This study considered gender diversity as an internal mechanism. It is calculated as "the percentage of female directors on the board to the total number of board of directors"(Thanh, Loi\& Yen, 2015). Some of the studies also take gender diversity as the dummy variables as its equal to 1 and zero otherwise (Nguyen et al., 2014). Gender diversity has a significant role in monitoring and controlling function. Females can improve decision making, monitoring functions, and the administrative processes on the board. Previous studies reported that females as the board of directors bring diversity and hence diversity brings different experiences and skills as well. Extant literature shows a positive impact of female directors on corporate performance as suggested by Adams and Ferreira, (2009). Nevertheless, studies conducted by various emerging economies reported different evidence. Some studies found negative while some reported no relationship (Maran and Indraah, 2009; Julizaerma \& Mohamad, 2012).

MCCG (2012) also mentioned in principle 2 "to establish a policy formalizing its approach to boardroom diversity and explicitly disclose in the annual report its gender diversity policies and targets and the measures taken to meet those targets." In Malaysia Codes of Corporate Governance (2017), it is recommended that a firm must have at least $30 \%$ female directors on the board as the board of directors rather than other staff. 


\section{Seven Characteristics of Good CG}

Management and BOD are accountable for the improvement of firm's performance in the listed firm. For better decision making, a company must take responsibility, and there must be a proper distribution of duties and responsibilities. The manager and board of directors must design some rules which help the firm to endorse each principle of good CG.

\section{Clear Strategy}

A firm must implement the CG codes for better corporate performance, and hence it starts with a clear strategy for the long run to avoid scandals and issues. For example, "a furniture company's management team might research the market to identify a profitable niche, create a product line to meet the needs of that target market, and then advertise its wares with a marketing campaign that reaches those consumers directly. At each stage, knowing the overall strategy helps the company's workforce stay focused on the organizational mission: meeting the needs of the consumers in that target market."

\section{Effective Risk Management}

If a firm makes all the necessary arrangements and implements smart policies, but still the risk of uncertainty will remain in the market such as (i) competitors can overstep in stealing their customers, (ii) an economic crisis can take place, (iii) unexpected disasters might cripple your operations, etc. to deal with this kind of unforeseen situations and manage the risk following are to be observed.

\section{Discipline}

Strategies, policies, and procedures are only effective if they are implemented and adopted in the practices. Making new strategies and policies are essential to deal with the current situation in the market, which also takes time and effort to push into new markets, but the initiative will fail if it cannot mobilize its workforce. To implement policies, resolutions, and strategies in a listed firm, there is a dire need of discipline in the stakeholder and management to accept the changes and recommendations.

\section{Fairness}

Being fair with the management, shareholders, the board of directors, investors, and other stakeholder must be a high priority for the ownership. For example, "managers must push their employees to be their best, but they should also recognize that a heavy workload can have negative long-term effects, such as low morale and high turnover.'Listed firms must be fair with their investor and provide accurate information to their stakeholders about the company's standings. A firm always gets hurtled by having the wrong 
policies of providing false information and mistreating customers in longterm prospects.

\section{Transparency}

Transparency in the system is essential to build the trust of the shareholder and investor in the firm. Internal directors limit the information themselves rather than sharing it with other employees. It is useful for the firm to share all the essential information and the actual standing of the firm and firm's profit and loss with another stakeholder, that will build trust and motivation to work in the firm and hence. Transparency is also essential for the investor, shareholder, and the general public and the government because it improves the market value of the firm.

\section{Social Responsibility}

The corporation is also recommended to be responsible for contributing to society, which is known as corporate social responsibility. Corporations and firms are not only to make a profit and produce goods, but the aim of the corporation must be the contribution to the society in different ways in the long run. Recycling and reducing wastage and pollution is one of the examples of corporate social responsibility. Good governance structure always promotes investment in society and pushes the firms to perform the activities that help the society in a better way.

\section{Self-Evaluation}

Firms make mistakes, no matter how perfect you manage the performance and then learn from it. The main focus must be on "performing regular self-evaluations to identify and mitigate brewing problems." The firm must hire official and professional consultants to analyze the firm's operations that help in the identification of several ways and modes for the company's efficiency in a better way.

\section{Conclusions and Recommendation}

Good governance is the key to avoiding agency costs, scandals, and misuse of the company's resources. The main objective of the corporate governance practice in a firm is to provide the structure where the roles and responsibilities are performed in the right way that improves firm's performance and its reputation, like by adopting good corporate governance structure with better monitoring and controlling function, accountability, and transparency in the statements. Shareholder's confidence and trust will help the firm to run smoothly in the long run and attract other foreign investors. This study highlighted the governance practice, associated problems, and scandals with the governance structure. It concluded that still the scandals and failure in corporate governance are happening in different parts, which 
give direction to the scholars to address the issue by conduction betterapplied research.

This study also reported the evolution of governance structure from 1992 to the current corporate practices and reports the improvement and betterment of governance structure and its policies. This study discusses the Malaysian codes of corporate governance (MCCG), its different mechanisms, and its revision in 2007, 2012, and 2017. In section 4, this study reports different problems and scandals that occur due to a lack of CG practice in the listed firm or by not adopting the principles of CG in the company's practices. Most of the theories only focus on the specific part of the governance structure and ignore the cultural values, political situation, economic stability, population and growth, peace and terror and social, religious, and implication of any structure and practice to adopt. This study highlights various theories and reports the importance of these theories in the practice of CG.

This study also focuses on the external and internal CG and its impact on corporate performance which addresses that there are various factors in the business and industrial market, which have a significant influence over firm's performance. To better control and cover these issues, there must be a proper implementation of CG practice that best suits the industrial and business environment in a specific economy.

Previous studies ignore the issue of endogeneity and perform the estimation using traditional static models, which gives biased results (Nguyen et al., 2014). This study recommends using dynamic models to avoid endogeneity because traditional estimation is being considered as biased by various studies that ignore the endogeneity between regressors. This study recommends conducting the study using dynamic models to better address and control the issue of endogeneity between regressors and reporting the valuable results. This study concludes that a study must be conducted in the various economies of the world and examine the factor that affects the practice of CG and find out the barrier in the adoption of CG. The study should be conducted in a dynamic framework where the issue of endogeneity and its better solution must be reported.

\section{References}

Adams, R.B., \& Ferreira, D. (2009). Women in the boardroom and their impact on governance and performance. Journal of Financial Economics, 94(2), 291-309.

Aduda, J., \& Musyoka, L. (2011). The relationship between executive compensation and firm performance in the Kenyan banking sector. Journal of Accounting and Taxation, 3(6), 130-139.

Aduda, J., Chogii, R., \& Magutu, P.O. (2013). An empirical test of competing corporate governance theories on the performance of firms 
listed at the Nairobi Securities Exchange. European Scientific Journal, 9(13).

Al-Malkawi, H.A.N., Arabia, S., Pillai, R., \& Dhabi, A. (2012). Internal mechanisms of corporate governance and firm performance: A review of theory and empirical evidence. Journal of Modern Accounting and Auditing, 8(4), 549.

Al-Swidi, A.K., \& Mahmood, R. (2012). Total quality management, entrepreneurial orientation and organizational performance: The role of organizational culture. African Journal of Business Management, 6(13), 4717.

Amran, N.A., \& Ahmad, A.C. (2011). Board mechanisms and Malaysian family companies' performance. Asian Journal of Accounting and Governance, 2, 15-26.

Bhatt, P.R., \& Bhatt, R.R. (2017). Corporate governance and firm performance in Malaysia. Corporate Governance: The international journal of business in society, 17(5), 896-912.

Briner, M., Kessler, O., Pfeiffer, Y., Wehner, T., \& Manser, T. (2010). Assessing hospitals' clinical risk management: Development of a monitoring instrument. BMC health services research, 10(1), 337.

Brown-Liburd, H., Cohen, J., \& Zamora, V.L. (2011). The Effect of Corporate Social Responsibility Investment, Assurance, and Perceived Fairness on Investors' Judgments.

Carter, E. (Ed.). (2010). B3ela Bal3azs: Early Film Theory: Visible Man and the Spirit of Film. Berghahn Books.

Dahawy, K. (2009). Developing nations and corporate governance: the story of Egypt. In The Global Corporate Governance Forum, The International Financial Corporation (IFC), $<$ http://www. ifc. org/ifcext/cgf. nsf/AttachmentsByTitle/PaperKhaledDahawy/\$ FILE/Dahawy_Kahled4. pdf.>. (accessed on September 24, 2010).

Davis, J.H., Allen, M.R., \& Hayes, H.D. (2010). Is blood thicker than water? A study of stewardship perceptions in family business. Entrepreneurship theory and practice, 34(6), 1093-1116.

Deegan, C. (2004). Environmental disclosures and share prices-a discussion about efforts to study this relationship. In Accounting Forum (Vol. 28, No. 1, pp. 87-97). Taylor \& Francis.

De Villiers, C., \& Van Staden, C.J. (2011). Where firms choose to disclose voluntary environmental information. Journal of Accounting and Public Policy, 30(6), 504-525.

Dezsö, C.L., \& Ross, D.G. (2012). Does female representation in top management improve firm performance? A panel data investigation. Strategic management journal, 33(9), 1072-1089.

Dorata, N.T., \& Petra, S.T. (2008). CEO duality and compensation in the market for corporate contr Wakaisuka-Isingoma, J., Aduda, J., Wainaina, G., \& Mwangi, C. I. (2016). Corporate governance, firm 
characteristics, external environment and performance of financial institutions in Uganda: A review of literature. Cogent Business \& Management, 3(1), 1261526.ol. Managerial Finance.

Drobetz, W., Gugler, K., \& Hirschvogl, S. (2009). 14. The determinants of German corporate governance ratings. The Modern Firm, Corporate Governance, and Investment, 361.

Ehikioya, B.I. (2009). Corporate governance structure and firm performance in developing economies: evidence from Nigeria. Corporate Governance: The international journal of business in society.

Erhardt, N.L., Werbel, J.D., \& Shrader, C.B. (2003). Board of director diversity and firm financial performance. Corporate governance: An international review, 11(2), 102-111.

Fama, E.F., \& Jensen, M.C. (1983). Agency problems and residual claims. The journal of law and Economics, 26(2), 327-349.

Fan, J.P., Wei, K.J., \& Xu, X. (2011). Corporate finance and governance in emerging markets: A selective review and an agenda for future research.

Fauzi, F., \& Locke, S. (2012). Board structure, ownership structure and firm performance: A study of New Zealand listed-firms.

Flannery, M.J., \& Hankins, K.W. (2013). Estimating dynamic panel models in corporate finance. Journal of Corporate Finance, 19, 1-19.

Ghazali, N.A.M. (2010). Ownership structure, corporate governance and corporate performance in Malaysia. International Journal of Commerce and Management.

Goncharov, I., Werner, J.R., \& Zimmermann, J. (2006). Does compliance with the German corporate governance code has an impact on stock valuation? An empirical analysis. Corporate governance: an international review, 14(5), 432-445.

Goh, C.F., Rasli, A., \& Khan, S.U.R. (2014). Economic incentives for family controlling shareholders and the monitoring role of nondominant large shareholders in corporate governance: Evidence from the manufacturing firms in Malaysia. South African Journal of Economic and Management Sciences, 17(4), 471-483.

Guo, Z., \& Kga, U.K. (2012). Corporate governance and firm performance of listed firms in Sri Lanka. Procedia-Social and Behavioral Sciences, 40, 664-667.

Haat, M.H.C., Rahman, R.A., \& Mahenthiran, S. (2008). Corporate governance, transparency and performance of Malaysian companies. Managerial Auditing Journal.

Haider, M., \& Khan, T. International Financial Reporting Standards, Accounting Conservatism, and Firm Performance: Evidence from UAE.

Haniffa, R., \& Hudaib, M. (2006). Corporate governance structure and performance of Malaysian listed companies. Journal of Business Finance \& Accounting, 33(7-8), 1034-1062. 
Hawley, J.P., \& Williams, A.T. (1996). Corporate governance in the United States: the rise of fiduciary capitalism. School of Economics and Business Administration.

Haji, A.A. (2014). The relationship between corporate governance attributes and firm performance before and after the revised code. International Journal of Commerce and Management.

Harris, M., \& Raviv, A. (2008). A theory of board control and size. The Review of Financial Studies, 21(4), 1797-1832.

Hussin, N., \& Othman, R. (2012). Code of corporate governance and firm performance. British Journal of Economics, Finance and Management Sciences, 6(2), 1-22.n evidence. Managerial auditing journal, 21(7), 783-804.

Ibrahim, M.Y., Ahmad, A.C., \& Khan, M.A. (2017). Does Corporate Governance Mechanism Improve Shareholder Value? A Panel Analysis of Malaysian Listed Companies. Global Business \& Management Research, 9.

Ibrahim, H., \& Samad, F.A. (2011). Corporate governance mechanisms and performance of public-listed family-ownership in Malaysia. International Journal of Economics and Finance, 3(1), 105-115.

Jackling, B., \& Johl, S. (2009). Board structure and firm performance: Evidence from India's top companies. Corporate Governance: An International Review, 17(4), 492-509.

Javed, S. (2013). Thermal response testing: Results and experiences from a ground source heat pump test facility with multiple boreholes.

Julizaerma, M.K., \& Sori, Z.M. (2012). Gender diversity in the boardroom and firm performance of Malaysian public listed companies. ProcediaSocial and Behavioral Sciences, 65, 1077-1085.

Kallamu, B.S., \& Saat, N.A.M. (2015). Audit committee attributes and firm performance: evidence from Malaysian finance companies. Asian Review of Accounting.

Khan, M.T., Al-Jabri, Q.M., \& Saif, N. Dynamic relationship between corporate board structure and firm performance: Evidence from Malaysia. International Journal of Finance \& Economics.

Kock, C.J., Santaló, J., \& Diestre, L. (2012). Corporate governance and the environment: what type of governance creates greener companies? Journal of Management Studies, 49(3), 492-514.

Kor, Y.Y., \& Misangyi, V.F. (2008). Outside directors' industry-specific experience and firms' liability of newness. Strategic Management Journal, 29(12), 1345-1355.

Kyereboah-Coleman, A., \& Biekpe, N. (2006). The relationship between board size, board composition, CEO duality and firm performance: Experience from Ghana. Corporate Ownership and Control, 4(2), 114122. 
La Porta, R., Lopez-de-Silanes, F., Shleifer, A., \& Vishny, R.W. (1997). Legal determinants of external finance. The journal of finance, 52(3), 1131-1150.

Marn, J.T.K., \& Romuald, D.F. (2012). The impact of corporate governance mechanism and corporate performance: A study of listed companies in Malaysia. Journal for the advancement of science \& arts, 3(1), 31-45.

Mustapa, I.R., Ghazali, N.A.M., \& Mohamad, M.H.S. (2015). The influence of corporate governance and organizational capacity on the performance of Malaysian listed companies. Mediterranean Journal of Social Sciences, 6(3 S1), 27-27.

Muzhar Javed, R.S., Lodhi, R.N., \& Malik, Q.U.Z. (2013). The effect of board size and structure on firm financial performance: A case of banking sector in Pakistan. Middle-East Journal of Scientific Research, 15(2), 243-251.

Myers, A.C. (1977). Sediment processing in a marine subtidal sandy bottom community: II. Biological consequences. J. mar. Res, 35(3), 633-647.

Nguyen, T., Locke, S., \& Reddy, K. (2014). A dynamic estimation of governance structures and financial performance for Singaporean companies. Economic Modelling, 40, 1-11.

Nielsen, S., \& Huse, M. (2010). The contribution of women on boards of directors: Going beyond the surface. Corporate governance: An international review, 18(2), 136-148.

Nicholson, G.J., \& Kiel, G.C. (2007). Can directors impact performance? A case-based test of three theories of corporate governance. Corporate Governance: An International Review, 15(4), 585-608.

Norwani, N.M., Zam, Z.M., \& Chek, I.T. (2011). Corporate governance failure and its impact on financial reporting within chosen companies. International Journal of Business and Social Science, 2(21).

Okiro, K. (2014). Corporate governance, capital structure, regulatory compliance and performance of firms listed at the East African community securities exchange. Unpublished PhD Thesis.

Ongore, V.O., \& K'Obonyo, P.O. (2011). Effects of selected corporate governance characteristics on firm performance: Empirical evidence from Kenya. International Journal of Economics and Financial Issues, 1(3), 99-122.

Pfeffer, J. (1972). Size and composition of corporate boards of directors: The organization and its environment. Administrative science quarterly, 218-228.

Ponnu, C.H. (2008). Corporate governance structures and the performance of Malaysian public listed companies. International Review of Business Research Papers, 4(2), 217-230.

Rahman, R.A., \& Ali, F.H.M. (2006). Board, audit committee, culture and earnings management: Malaysia. 
Raheja, C.G. (2005). Determinants of board size and composition: A theory of corporate boards. Journal of financial and quantitative analysis, 40(2), 283-306.

Rahim, A.R., Yaacob, H.M., Alias, N., \& Nor, M.F. (2010). Investment, board governance and firm value: A panel data analysis. International review of business research papers, 6(5), 293-302.

Rahman, H.U., Rehman, S., Zahid, M., Jan, A., \& Rehman, A. (2019). Does Corporate Governance Prevent Corporate Debacles?: A Comparative Analysis of the US and Malaysian Bankrupted Corporations. In Corporate Insolvency Law and Bankruptcy Reforms in the Global Economy (215-232).

Rezaei, F., \& Jalilmehr, M. (2012). Influence of Corporate Governance on Accounting Outcomes \& Firms Performance'. Interdisciplinary Journal of Contemporary research in business, 3(10).

Riaz, S., Khan, A.H., \& Shaheen, M. (2017). Relationship between Board Size And Firm Performance: Intervening Role Of Policies. Bulletin of Business and Economics (BBE), 6(3), 130-140.

Rodríguez-Fernández, A., Ramos-Díaz, E., Madariaga, J.M., Arrivillaga, A., \& Galende, N. (2016). Steps in the construction and verification of an explanatory model of psychosocial adjustment. European Journal of Education and Psychology, 9(1), 20-28.

Ruback, R.S., \& Jensen, M.C. (1983). The market for corporate control: The scientific evidence. Journal of Financial economics, 11, 5-50.

Saad, N.M. (2010). Corporate governance compliance and the effects to capital structure in Malaysia. International Journal of Economics and Finance, 2(1), 105-114.

Saif, N., Khan, M.T., Ali, S., \& Wadood, F. (2019). Laohavichien model of Leadership and Quality for Pakistan. What it is and why it's important for SME's. IBT Journal of Business Studies (JBS), 15(2), 43 - 61.

Sanders, W.G., \& Carpenter, M.A. (1998). Internationalization and firm governance: The roles of CEO compensation, top team composition, and board structure. Academy of Management journal, 41(2), 158-178.

Schultz, E.L., Tan, D.T., \& Walsh, K.D. (2010). Endogeneity and the corporate governance-performance relation. Australian journal of management, 35(2), 145-163.

Sheikh, N.A., \& Kareem, S. (2015). The impact of board structure, ownership concentration, and CEO remuneration on performance of Islamic commercial banks in Pakistan. Pakistan Journal of Islamic Research, 15, 49-59.

Shakir, R. (2009). Soft skills at the Malaysian institutes of higher learning. Asia Pacific Education Review, 10(3), 309-315.

Shukeri, S.N., Shin, O.W., \& Shaari, M.S. (2012). Does board of director's characteristics affect firm performance? Evidence from Malaysian public listed companies. International Business Research, 5(9), 120. 
Shleifer, A., \& Vishny, R.W. (1997). A survey of corporate governance. The journal of finance, 52(2), 737-783.

Singh, V., Terjesen, S., \& Vinnicombe, S. (2008). Newly appointed directors in the boardroom: How do women and men differ? European management journal, 26(1), 48-58.

Sun, P., Mellahi, K., \& Liu, G.S. (2011). Corporate governance failure and contingent political resources in transition economies: A longitudinal case study. Asia Pacific Journal of Management, 28(4), 853-879.

Suchman, M.C. (1995). Managing legitimacy: Strategic and institutional approaches. Academy of management review, 20(3), 571-610.

Tu, T.T.T., Loi, H.H., \& Yen, T.T.H. (2015). Research on the impact of rural household credit access to sustainable poverty reduction in Vietnam. In World Finance and Banking Symposium 2015.

Ur Rehman, Z., Zahid, M., Rahman, H.U., Asif, M., Alharthi, M., Irfan, M., \& Glowacz, A. (2020). Do Corporate Social Responsibility Disclosures Improve Financial Performance? A Perspective of the Islamic Banking Industry in Pakistan. Sustainability (2071-1050), 12(8).

Ujunwa, A. (2012). Board characteristics and the financial performance of Nigerian quoted firms. Corporate Governance: The international journal of business in society.

Van Staden, S., \& Bosker, R. (2014). Factors that affect South African reading literacy achievement: evidence from prePIRLS 2011. South African Journal of Education, 34(3).

Waweru, N.M., \& Riro, G.K. (2013). Corporate governance, firm characteristics and earnings management in an emerging economy. Journal of Applied Management Accounting Research, 11(1), 43.

Wintoki, M.B., Linck, J.S., \& Netter, J.M. (2012). Endogeneity and the dynamics of internal corporate governance. Journal of Financial Economics, 105(3), 581-606.

Yusoff, W.F.W., \& Alhaji, I.A. (2012). Insight of corporate governance theories. Journal of Business and management, 1(1), 52-63.

Zahid, M., Rahman, H.U., Ali, W., Khan, M., Alharthi, M., Qureshi, M.I., \& Jan, A. (2020). Boardroom gender diversity: Implications for corporate sustainability disclosures in Malaysia. Journal of Cleaner Production, 244, 118683.

Zahid, M., Rahman, H.U., \& Asif, M. (2019). The Bond between Board and Performance: A Case of the Banking Industry of Pakistan. NUML International Journal of Business \& Management, 14(2), 128-139. 